\title{
Looking Forward: Using Scenario Modeling to Support Regional Land Use Planning in Northern Yukon, Canada
}

\author{
$\underline{\text { Shawn R. Francis }}^{1}$ and Jeff Hamm $^{2}$
}

\begin{abstract}
Regional land use planning provides opportunities for governments, land users, and stakeholders to consider multiple land and resource interests over large geographic areas and meaningful time periods. The broad and integrative nature of regional planning is therefore well suited to assessing the potential cumulative effects of current and future land use activity. For this reason, cumulative effects assessment models and management concepts are playing an increasingly important role in regional planning. We describe how the ALCES $®$ landscape cumulative effects simulation model was used to explore possible outcomes of an oil and gas scenario in the Eagle Plain basin of the North Yukon Planning Region of Yukon Territory, Canada. Scenario modeling was conducted to facilitate informed discussion about key land use issues and practices, potential levels of landscape change, and possible socioeconomic benefits and environmental impacts. Modeling results supported the sustainable development and cumulative effects management recommendations of the North Yukon Regional Land Use Plan. Land use scenario modeling, as applied in this project, was found to be an effective approach for establishing sustainable development guidelines through a regional planning process.
\end{abstract}

Key Words: ALCES®; cumulative effects; Eagle Plain; land use planning; limits of acceptable change; moose; North Yukon; Porcupine caribou herd; scenario modeling; Vuntut Gwitchin; Yukon Government

\section{INTRODUCTION}

Northern Canada is undergoing considerable social, economic, political, and ecological change. Aboriginal communities desire to maintain strong cultural and traditional economic ties to the land, but also wish to participate in modern wage-based economic activities. Increasing interest in economic development, including oil and gas, mining, tourism, and transportation, is providing employment and wages but is also resulting in adverse social and ecological effects. Climate change has the potential to result in high levels of ecological change (Hinzman et al. 2005), with associated effects on cultural systems (ACIA 2005).

Regional land use planning is a possible mechanism for preparing for and managing the magnitude and pace of change. In Yukon Territory, Canada, recent land claim agreements and the devolution of federal management responsibilities to territorial and First Nation governments have given rise to new environmental assessment and land and resource decisionmaking processes (e.g., Yukon Environmental and Socioeconomic Assessment Act 2003). These land claim agreements provide opportunities for planning commissions with equal participation from government, First Nations, and communities to prepare land use plans. The plans must, as core principles, incorporate traditional knowledge and experience, be built through consensus, and promote sustainable development (Government of Yukon, Council of Yukon Indians and Government of Canada 1993a). While this represents a new paradigm for First Nation participation in land and resource management in Yukon, it is not without significant challenges.

${ }^{1}$ ALCES Landscape and Land-Use Ltd., ${ }^{2}$ Geoplan Consulting
Generally, the preparation of a regional land use plan requires the formulation of value statements and decisions about the future. What are the cultural and ecological values we strive to protect? What are our economic objectives? What level and type of land use activity will result in the economic benefits we hope to achieve? What level of risk are we prepared to accept? Will anticipated land use activity result in unacceptable risks to our cultural and ecological values? To be effective, regional planning must understand the future consequences of today's decisions, and evaluate whether those decisions will achieve the desired results. Having the capacity to look forward, and understand and evaluate possible alternative futures, is therefore required.

The development and analysis of land use scenarios is an effective method of evaluating possible alternative futures. Land use scenarios describe a model or outline of plausible land uses that might occur, including possible timelines, benefits, and impacts (Xiang and Clarke 2003, Mahmoud et al. 2009). Scenario development provides a structured approach to dealing with future uncertainty. Also, in the context of regional planning, scenario development requires participants to clearly state assumptions and desired outcomes, leading to greater clarity and understanding. Simulation models allow the scenarios to be projected forward, and the potential risks and benefits of different outcomes to be explored and evaluated.

Achieving sustainable development requires understanding and managing the adverse cumulative impacts of multiple land use activities. In Canada, the linkage between regional land use planning and cumulative effects assessment and 
management has received much attention (Kennett 1999, Greig et al. 2004, Duinker and Greig 2006). There is growing consensus that conducting cumulative effects assessments as part of scenario-based regional planning is more effective than the current practice of sectoral planning or project-based assessment. Regional planning is well positioned to examine the possible outcome of multiple land uses over meaningful time scales and large geographic areas-similar goals as cumulative effects assessment. Further, regional planning has the potential to implement cumulative effects management tools and approaches as part of plan implementation. For these reasons, cumulative effects assessment models and management concepts are playing an increasingly important role in regional planning.

We describe how the ALCES $^{\oplus}$ landscape cumulative effects simulation model (ALCES 2011) was used to explore outcomes of potential oil and gas development in the Eagle Plain basin of the North Yukon Planning Region (NYPR) of Yukon Territory, Canada (Fig. 1). Results are summarized and discussed. A brief overview of the North Yukon Regional Land Use Plan (NYRLUP) is provided. How the scenario modeling results contributed to the NYRLUP management recommendations is also described.

Fig. 1. Location of North Yukon Planning Region.

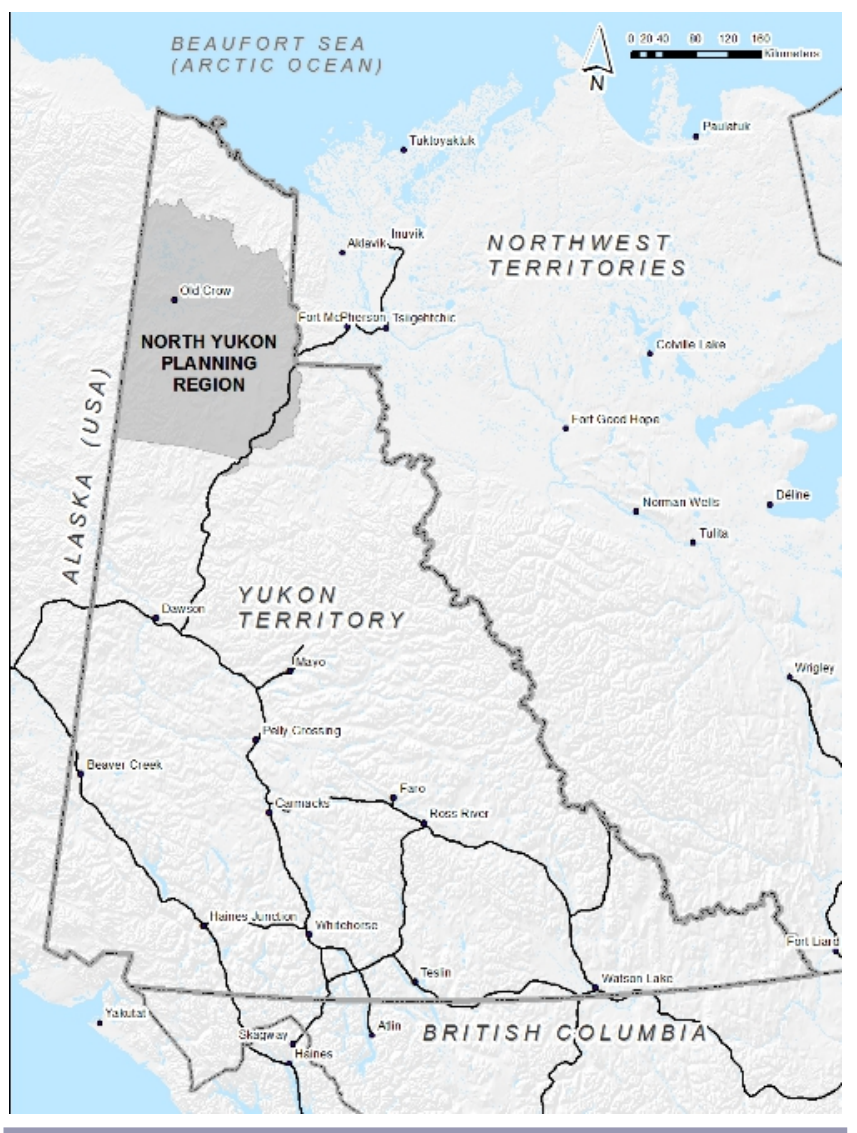

\section{About the North Yukon Regional Land Use Plan}

The Vuntut Gwitchin First Nation Final Agreement (VGFNFA) was signed in 1993 and contains provisions for establishing a planning commission to conduct regional land use planning (Government of Yukon, Council of Yukon Indians and Government of Canada 1993b). The NYPR is the traditional territory of the Vuntut Gwitchin First Nation (VGFN). In 2007, after a four-year public process, the North Yukon Planning Commission (NYPC) submitted the draft NYRLUP for consideration by the Yukon and Vuntut Gwitchin governments (NYPC 2007a). Under the VGFNFA, the Yukon and First Nation governments have joint approval and implementation responsibilities for the land use plan. The NYRLUP was approved in June 2009 (Yukon Government and Vuntut Gwitchin Government 2009).

As part of its sustainable development mandate, a major goal of the NYRLUP was to recommend measures to minimize the adverse cumulative effects of land use. To achieve this goal, the NYPC required an understanding of potential levels of change resulting from land use and natural processes. Establishing limits of acceptable change (Macleod Institute 2002) for two integrated cumulative effects indicators, total surface disturbance and linear density (Salmo et al. 2004), was adopted as a relevant and practical approach for managing potentially adverse cumulative effects. The scenario modeling project we describe was initiated to support the cumulative effects management recommendations of the NYRULP.

The NYRLUP includes a zoning system with protected, integrated management, and community areas. The integrated management area (IMA) is the working landscape where oil and gas, mineral development, and other industrial activities can occur. The IMA includes four zones organized on the concept of acceptable levels of human-caused change and potential risks to ecological and cultural resources (Table 1). Two integrated indicators of cumulative effects, total surface disturbance and linear density, are part of the zone definitions and help define the relative level of conservation or development focus in each zone. Critical and cautionary indicator levels are defined for each IMA zone. Consideration of economic, ecological, and cultural values results in different zone designations for different IMA units (Fig. 2).

\section{Planning region overview \\ Geographic and ecological setting}

The NYPR is $55,548 \mathrm{~km}^{2}$ in area, encompassing 12 percent of Yukon Territory, Canada (Fig. 1). The NYPR is part of Beringia, an area spanning Yukon, Alaska, and Siberia that remained ice-free during successive periods of continental glaciations over the past two million years (Hopkins et al. 1982, Duk-Rodkin 1999). Much of the region is north of the Arctic Circle, and continuous permafrost underlies most of the area (Smith et al. 2004). Winter temperatures average $-35^{\circ} \mathrm{C}$, while summer temperatures occasionally reach $30^{\circ} \mathrm{C}$ (Wahl et al. 1987). 
Table 1. North Yukon Regional Land Use Plan integrated management area (IMA) zoning system and recommended cumulative effects (CE) indicator levels. Adapted from Yukon Government and Vuntut Gwitchin Government (2009).

\begin{tabular}{|c|c|c|c|c|c|}
\hline $\begin{array}{l}\text { IMA } \\
\text { zone } \\
\end{array}$ & $\begin{array}{c}\text { Management } \\
\text { intent }\end{array}$ & Description & $\begin{array}{c}\mathrm{CE} \\
\text { indicator }\end{array}$ & $\begin{array}{c}\text { Cautionary } \\
\text { level } \dagger\end{array}$ & $\begin{array}{c}\text { Critical } \\
\text { level }\end{array}$ \\
\hline \multirow[t]{2}{*}{ Zone I } & $\begin{array}{c}\text { Lowest } \\
\text { development }\end{array}$ & $\begin{array}{l}\text { Very high ecological and heritage/cultural } \\
\text { values within a sensitive biophysical setting. } \\
\text { Maintaining ecological integrity and } \\
\text { protecting heritage and cultural resources is } \\
\text { the priority. All-season industrial } \\
\text { infrastructure is discouraged. }\end{array}$ & $\begin{array}{c}\text { Surface } \\
\text { disturbance }\end{array}$ & $0.075 \%$ & $0.1 \%$ \\
\hline & & & $\begin{array}{l}\text { Linear } \\
\text { density }\end{array}$ & $0.075 \mathrm{~km} / \mathrm{km}^{2}$ & $0.1 \mathrm{~km} / \mathrm{km}^{2}$ \\
\hline \multirow[t]{2}{*}{ Zone II } & $\begin{array}{c}\text { Low } \\
\text { development }\end{array}$ & $\begin{array}{l}\text { High ecological and heritage/cultural values } \\
\text { within a moderately sensitive biophysical } \\
\text { setting. Maintaining ecological integrity, } \\
\text { protecting heritage and cultural resources, } \\
\text { and minimizing land use impacts is the } \\
\text { priority. }\end{array}$ & $\begin{array}{c}\text { Surface } \\
\text { disturbance }\end{array}$ & $0.15 \%$ & $0.2 \%$ \\
\hline & & & $\begin{array}{l}\text { Linear } \\
\text { density }\end{array}$ & $0.15 \mathrm{~km} / \mathrm{km}^{2}$ & $0.2 \mathrm{~km} / \mathrm{km}^{2}$ \\
\hline \multirow[t]{2}{*}{ Zone III } & $\begin{array}{c}\text { Moderate } \\
\text { development }\end{array}$ & $\begin{array}{l}\text { Moderate ecological and heritage/cultural } \\
\text { values within a moderately sensitive } \\
\text { biophysical setting. Conservative levels of } \\
\text { land use are consistent with Zone III } \\
\text { objectives. }\end{array}$ & $\begin{array}{c}\text { Surface } \\
\text { disturbance }\end{array}$ & $0.375 \%$ & $0.5 \%$ \\
\hline & & & $\begin{array}{l}\text { Linear } \\
\text { density }\end{array}$ & $0.375 \mathrm{~km} / \mathrm{km}^{2}$ & $0.5 \mathrm{~km} / \mathrm{km}^{2}$ \\
\hline \multirow[t]{2}{*}{ Zone IV } & $\begin{array}{c}\text { Highest } \\
\text { development }\end{array}$ & $\begin{array}{l}\text { Lower ecological and heritage/cultural } \\
\text { values within a moderately sensitive } \\
\text { biophysical setting. Higher levels of land } \\
\text { use are consistent with Zone IV objectives. }\end{array}$ & $\begin{array}{c}\text { Surface } \\
\text { disturbance }\end{array}$ & $0.75 \%$ & $1.0 \%$ \\
\hline & & & $\begin{array}{l}\text { Linear } \\
\text { density }\end{array}$ & $0.75 \mathrm{~km} / \mathrm{km}^{2}$ & $1.0 \mathrm{~km} / \mathrm{km}^{2}$ \\
\hline
\end{tabular}

$\dagger$ Cautionary cumulative effects indicator level is established as $75 \%$ of the upper or critical level. Indicator levels are calculated for each landscape management unit of the Integrated Management Area.

The region is ecologically diverse, with rolling forested plateaus, major wetland complexes, large rivers, and rugged mountainous areas with expanses of shrub and tundra-like vegetation (Smith et al. 2004). Approximately half of the NYPR is forested, with Arctic tundra occurring in the northern portion of the region. Elevation ranges from $325 \mathrm{~m}$ in Old Crow Flats to $1800 \mathrm{~m}$ in the North Ogilvie Mountains. Most of the region is within the Porcupine River watershed. Major tributaries include the Old Crow, Eagle, Bell, Whitestone, and Fishing Branch rivers. Rivers experience very low winter flows and dramatic variations in flow during summer.
The NYPR is occupied seasonally or annually by approximately 40 species of mammals, 150 species of birds, and 18 species of fish, including three species of salmon (NYPC 2007b). The barren-ground Porcupine Caribou Herd (Russell et al. 1993) is the most significant wildlife resource in the planning region, and is a vital cultural and economic resource for the community of Old Crow and neighboring Gwich'in communities.

Three protected areas cover about one third of the region. Vuntut National Park, Old Crow Flats Special Management 
Area, and Ni'iinlii'njik (Fishing Branch) Wilderness Preserve are co-managed by the Vuntut Gwitchin Government, the Yukon Government, and responsible federal agencies.

Fig. 2. Zoning considerations for the North Yukon Regional Land Use Plan integrated management area.

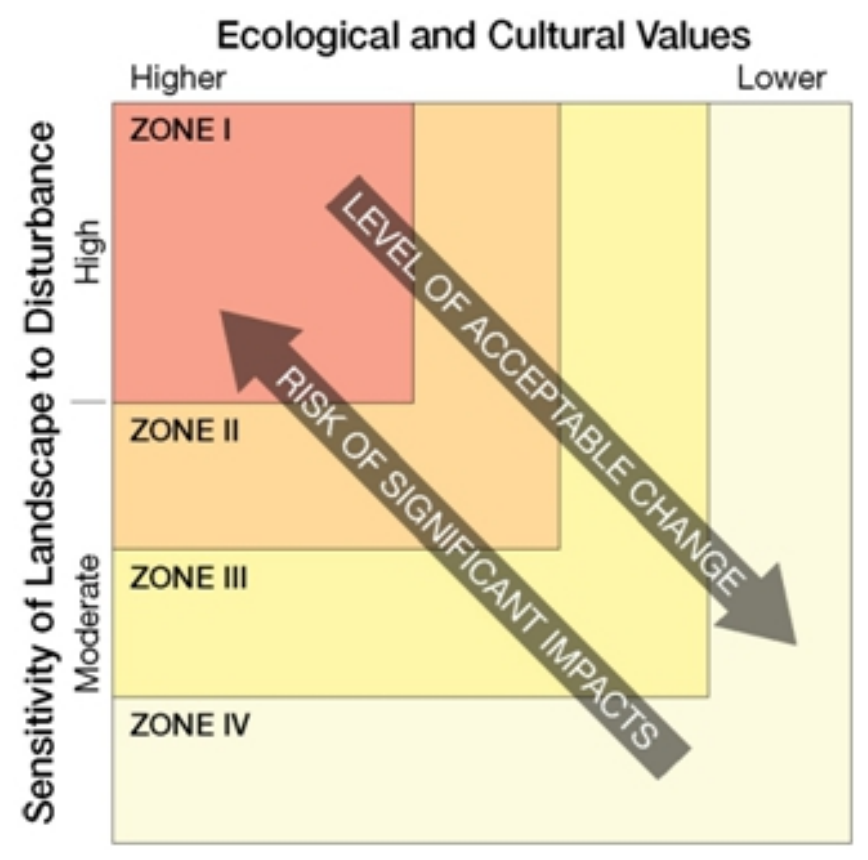

People and economy

Old Crow is the only permanent community in the region, with a population of about 300 people. Almost all residents are VGFN citizens. Old Crow is the only community in Yukon without all-season road access, but it is serviced year-round by air or occasionally by winter road. The Dempster Highway runs through the southeastern portion of the NYPR, connecting southern Yukon with the Mackenzie River delta communities in Northwest Territories. It is the only major allseason road in northern Yukon.

The regional economy is a "mixed economy" where both traditional subsistence harvesting and wage-based activities co-exist (Berman and Kofinas 2004). Subsistence hunting, gathering, and trapping are still very important economic and cultural activities in Old Crow. Transportation and government services are the most significant sources of wagebased employment.

Activity in most other land use sectors is currently low but increasing. Wilderness and community-based tourism is expanding. While there are no operating mines, mineral exploration activity has recently increased. There is no commercial forestry or agriculture. The Eagle Plain oil and gas basin received a high level of exploration in the 1960s70s and is considered to be one of Yukon's most promising areas for future natural gas production. Current estimates identify the potential for 7.9 trillion cubic feet of natural gas and moderate oil potential for 536 million barrels (Osadetz et al. 2005). Most tourism, oil and gas, and mining interests and activities occur along the Dempster Highway corridor.

\section{Key planning issues}

Recommending measures to protect regional ecological integrity and Vuntut Gwitchin culture, traditional economy, and heritage resources while providing opportunities for economic development activities and wage-based employment was the central challenge facing the NYPC (NYPC 2007a, $b$ ). The NYRLUP attempts to balance potential risks to ecological and cultural resources with the requirement for, and potential impacts of, economic development (Yukon Government and Vuntut Gwitchin Government 2009).

Understanding and managing the cumulative impacts of potential oil and gas exploration and development in Eagle Plain, and the possible effects of climate change (Hinzman et al. 2005), were identified as the most significant ecological planning issues by community members and stakeholders (NYPC 2007a, b). Of special concern were potential impacts to barren-ground caribou and moose, and their habitats. The scenario modeling we describe, therefore focused on potential energy sector activity in the Eagle Plain basin (Fig. 3).

The NYPC considered scenario modeling to be an effective approach to better understanding the potential risks and benefits of oil and gas exploration and development, the key issue of the NYRLUP. Further, the community of Old Crow was familiar with the concepts of scenario modeling through previous initiatives (Berman et al. 2004, Kruse et al. 2004). The ALCES ${ }^{\circledR}$ model was selected as the North Yukon scenario modeling tool due to its prior application towards similar land use issues in other jurisdictions (e.g., Schneider et al. 2003).

\section{METHODS}

ALCES $®$ landscape cumulative effects simulation model The ALCES ${ }^{\circledR}$ landscape cumulative effects simulation model (ALCES 2011) was used to examine possible outcomes of an oil and gas scenario in the Eagle Plain basin of the NYPR. ALCES $^{\circledR}$ is a stock and flow model built in the Stella/iThink software environment (isee systems 2010). The ALCES ${ }^{\circledR}$ model has been used in western and northern Canada, and has recently been deployed in other jurisdictions, including Australia. ALCES ${ }^{\circledR}$ simulates and tracks current and future land use footprints and other indicators based on user-defined parameters. ALCES ${ }^{\circledR}$ allows users to define land use scenarios and project their potential outcomes into the future. The model enables users to explore and quantify dynamic landscapes affected by single or multiple human land use practices and various natural disturbance regimes such as fire and flooding. ALCES $^{\circledR}$ was specifically developed to assist resource managers, planners, and communities in the following areas: 
- track anthropogenic footprints and economic contributions of different land uses;

- identify and communicate ecological and land use issues; and

- explore mitigation strategies for issues related to the maintenance of ecological (e.g., wildlife habitat quality), social (e.g., population), and economic (e.g., employment and royalty revenues) goals.

Fig. 3. Eagle Plain study area within the North Yukon Planning Region.

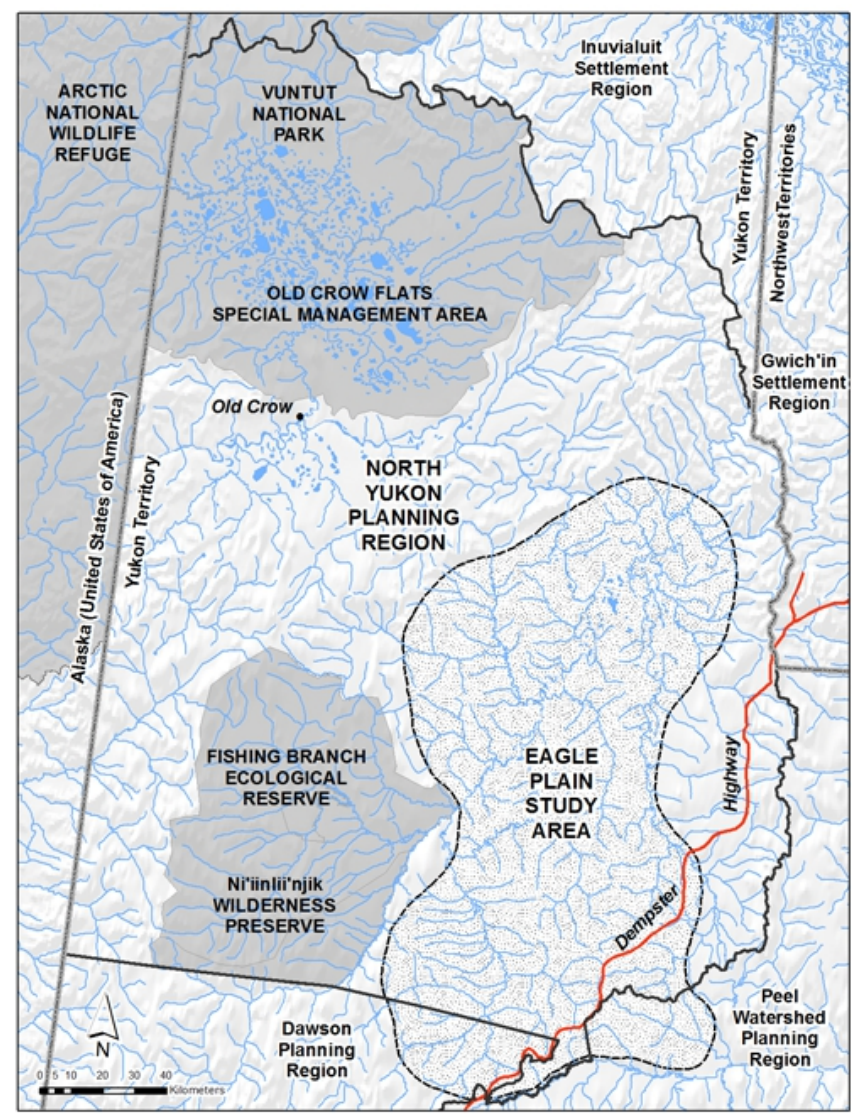

ALCES $^{\circledR}$ uses a spatially stratified approach to track land use activities and natural disturbance regimes. The model stratifies landscapes based on user-defined "landscape types" and assigns user-defined "land use footprints", trajectories, and reclamation rates for each land use based on proportions and rates. Land use footprints are tracked based on their proportional representation within each landscape type.

Some factors may have major effects on the rate and magnitude of landscape change. In the ALCES ${ }^{\circledR}$ model, the relative influence of land use activities and practices (e.g., oil and gas, tourism, or mining), natural disturbance regimes (e.g., fire or forest insects), and climatic effects (e.g., climate change) can be isolated and examined. In this manner, ALCES ${ }^{\circledR}$ provides a framework for evaluating the potential significance of different natural and human land use factors. Model outputs are in the form of numeric tables or line and bar charts.

\section{Scenario development}

The oil and gas scenario was developed to address key planning issues and understand the potential cumulative impacts of energy sector activity in the Eagle Plain area of the NYPR (Fig. 3). The Eagle Plain oil and gas scenario was originally developed by Fekete (2006), and was further refined by the NYPC and the Yukon Oil and Gas Management Branch (Table 2). Current understanding of hydrocarbon potential (Osadetz et al. 2005) suggests that natural gas would be the most likely focus of future activity, although some oil production for local consumption could also occur. Construction of the Mackenzie Valley Pipeline (Mackenzie Gas Project 2010) in the adjacent Northwest Territories, and a lateral pipeline along the Dempster Highway to Yukon, was considered to be a necessary catalyst for natural gas development in Eagle Plain.

Table 2. Overview of Eagle Plain oil and gas scenario.

\begin{tabular}{ll}
\hline \hline $\begin{array}{l}\text { Land } \\
\text { use } \\
\text { sector }\end{array}$ & Description \\
\hline $\begin{array}{l}\text { Oil } \\
\text { and } \\
\text { gas }\end{array}$ & Study Area: Eagle Plain \\
& Scenario Summary: \\
& Natural Gas Scenario \\
& • Exploration phase (2010-2020) \\
& - Pipeline construction phase (2020-2025) \\
& - Dempster lateral pipeline to Mackenzie Valley \\
& Pipeline \\
& - Transportation and distribution infrastructure \\
& - Production phase (2025-2055; 2.0 trillion cubic \\
& feet production) \\
& Oil Scenario \\
& • Exploration and testing (current-2012) \\
& - Production of local fuel oil (2012-2055; 2.74 \\
& million barrels production) \\
\hline
\end{tabular}

A number of different oil and gas scenarios for Eagle Plain were not examined because the range of plausible scenarios was considered to be relatively low. Therefore, the modeling exercise focused on comparing the potential effect of different operating practices and methods of extracting approximately 2 trillion cubic feet (5.6 billion cubic meters) of natural gas and 2.74 million barrels (435,000 cubic meters) of oil over a 30 -year period on selected indicators. The transportation capacity of a Dempster Highway lateral pipeline was considered to be a primary constraint on natural gas production levels (Fekete 2006). 
The Eagle Plain oil and gas scenario may be considered an anticipatory, stakeholder-defined projection of possible future development (Mahmoud et al. 2009). Numerous technical meetings were held with government agency and sector specialists to develop detailed scenario parameters and assumptions. Community input did not directly inform the technical aspects of the oil and gas scenario, but played an important role in the identification of ecological values and issues. Technical discussions were integral to the modeling effort, and assisted in fostering increased understanding of key issues and operating practices between planners and sector specialists.

\section{Populating the ALCES $®$ model}

To prepare for scenario modeling, data were gathered or created to describe the biophysical and climate characteristics of the region, land use growth rates and parameters (including footprint reclamation rates and trajectories), and wildlifehabitat relationships (including possible wildlife responses to human features and activities). A variety of information sources was used, including published literature (e.g., Russell et al. 1993, Nelleman and Cameron 1998, Tromulak and Frissell 2000, Berman et al. 2004, Kruse et al. 2004, Cameron et al. 2005, and Hinzman et al. 2005), government and industry domain experts and reports (e.g., Osadetz et al. 2005, Fekete 2006), and community of Old Crow land user knowledge workshops (for barren-ground caribou and moose habitat models). A full description of information compiled in support of this exercise is contained in the NYPR Resource Assessment Report (NYPC 2007b).

\section{Conducting scenario modeling}

Scenario modeling was conducted in the Eagle Plain Study Area, a sub-region of the NYPR (Fig. 3). A 100-year simulation period was selected to examine the full cycle of potential hydrocarbon production (exploration, production, and reclamation).

The estimated range of natural variability (RNV) was used as a benchmark to compare barren-ground caribou and moose indicator response to the oil and gas scenario. RNV was estimated in the following manner. Using GIS, all current land use features were removed from the study area landscape map. Monte Carlo simulations were then used to stochastically model habitat conditions based on calculated fire size and fire return intervals, and vegetation succession. Ninety-five percent confidence intervals were then calculated to represent expected pre-disturbance RNV of barren-ground caribou and moose habitat conditions within Eagle Plain.

Sensitivity analysis was used to explore the potential effect of varying oil and gas infrastructure parameters (seismic line width and well site aggregation) and footprint revegetation rates on ecological and disturbance indicators. Potential climate change effects (increasing fire rate, vegetation transitions, and changing snow conditions) on barren-ground caribou and moose habitat quality were also examined.

\section{Indicators}

Socioeconomic and ecological indicators were selected based on relevant cultural and resource values, and key planning issues (Table 3). Barren-ground caribou winter and moose late-fall habitat suitability and effectiveness, human-caused surface disturbance and linear density, and economic metrics, such as employment and commodity production, were reported.

\section{RESULTS}

\section{Socioeconomic outcomes}

Results for the Eagle Plain oil and gas scenario are summarized in Table 4. Modeling results suggest that based on the assumed level of oil and gas production, 120 full-time equivalent (FTE) exploration positions and 300-350 FTE production positions would be generated annually, for a period of 20-30 years. Wage generation from these positions was estimated to be \$25-36 million annually. Potential revenue, based on fixed commodity price assumptions ( $\$ 10 /$ million cubic feet natural gas; $\$ 60 /$ barrel oil), ranged from $\$ 530$ million to $\$ 1.2$ billion annually.

Increasing energy sector activity was not expected to result in a major change in regional population because most activity would occur a large distance from Old Crow, with employees being housed in work camps. However, the number of energy sector workers in the region would be similar to the current population of Old Crow for a period of at least 30 years.

\section{Ecological and land use outcomes}

Modeled results for maximum levels of surface disturbance ranged from approximately 7500 ha to 20,000 ha, depending on operating practice and reclamation assumptions (discussed further in Sensitivity analysis). Maximum linear density levels ranged between 0.7 and $1.3 \mathrm{~km} / \mathrm{km}^{2}$.

The modeled direct and indirect habitat impacts of energy sector activity resulted in reduced barren-ground caribou winter Habitat Effectiveness Index (HEI) and moose late-fall HEI. Reduction of HEI value ranged from 20 to 40 percent, compared with undisturbed habitat conditions. Through sensitivity analysis, energy sector operating practices and snow conditions were found to a have large influence on indicator outcomes.

\section{Sensitivity analysis \\ Energy sector operating practices}

Energy sector operating practices have the potential to decrease levels of surface disturbance and linear density, with corresponding increases in barren-ground caribou and moose HEI. Seismic line widths, and the reclamation rate of those features, are important factors affecting maximum levels of surface disturbance and linear density (Table 5). However, well aggregation (increasing the number of oil or gas wells on each well pad) results in the largest decrease in surface disturbance, primarily as a result of decreased length of access 
Table 3. Eagle Plain oil and gas scenario indicators.

\begin{tabular}{|c|c|c|}
\hline Indicator type & Indicator & Description \\
\hline \multirow[t]{6}{*}{ Socioeconomic } & Commodity production & Amount of commodity produced by oil and gas activity \\
\hline & Revenue & Dollar (\$) value of commodity production \\
\hline & Employment & Full-time equivalent annual employment \\
\hline & Wages & Dollar (\$) value of annual wages earned by sector employees \\
\hline & Royalties & Dollar (\$) value of annual resource sector royalties generated \\
\hline & Regional human population & Full-time resident human population \\
\hline \multirow[t]{5}{*}{ Land use and ecological } & Land use infrastructure & $\begin{array}{l}\text { Infrastructure metrics that aid in better understanding surface disturbance and } \\
\text { linear density indicators }\end{array}$ \\
\hline & Surface disturbance & $\begin{array}{l}\text { Total amount of direct human-caused surface disturbance (i.e., direct land use } \\
\text { footprint) expressed as percent of study area or ha }\end{array}$ \\
\hline & Linear density & $\begin{array}{l}\text { Total length of linear features (roads, seismic lines, and trails) within a given } \\
\text { area, expressed as } \mathrm{km} / \mathrm{km}^{2}\end{array}$ \\
\hline & Habitat Suitability Index (HSI) & $\begin{array}{l}\text { Relative ranking of wildlife habitat quality in the absence of potential human- } \\
\text { caused habitat effects. HSI values range from } 0 \text { (no habitat value) to } 1 \text { (perfect } \\
\text { habitat value). Indicator is used for range of natural variability runs. Two } \\
\text { wildlife focal species HSI indicators were examined: barren-ground caribou } \\
\text { winter HSI, and moose late-fall HSI }\end{array}$ \\
\hline & $\begin{array}{l}\text { Habitat Effectiveness Index } \\
\text { (HEI) }\end{array}$ & $\begin{array}{l}\text { Relative ranking of wildlife habitat quality, with consideration of potential } \\
\text { human-caused habitat effects. Like HSI, HEI values range from } 0 \text { (no habitat } \\
\text { value) to } 1 \text { (perfect habitat value). HEI can be compared against HSI to } \\
\text { understand potential land use impacts. Two wildlife focal species HEI } \\
\text { indicators were examined: barren-ground caribou winter HEI, and moose late- } \\
\text { fall HEI }\end{array}$ \\
\hline
\end{tabular}

roads, and the corresponding effect on gravel requirements (Table 5).

\section{Snow conditions and barren-ground caribou}

Climate change was identified as an important issue for the NYRLUP. Climate-induced changes that may affect barrenground caribou and moose habitat suitability include vegetation transition, variation of winter snow depth and snowpack density, and increasing fire rates (Hinzman et al. 2005). Of these potential effects, only winter snow conditions were found to have a major impact on barren-ground caribou winter habitat quality in the Eagle Plain Study Area (this was not a major factor for moose). Compared with good (low depth) snow conditions, poor (high depth) snow condition resulted in an approximate 70 percent reduction in habitat value, decreasing from an average of 0.68 to 0.20 .

\section{DISCUSSION}

\section{Scenario results}

The Eagle Plain oil and gas scenario represents a land use activity with the potential to generate significant economic benefits but that also poses potential ecological risks. Commodity production and price is the primary driver of potential revenue and employment; higher or lower prices and levels of production will result in changed economic results (revenue and employment).
The assumptions surrounding the North Yukon oil and gas scenario, as modeled in this project, were generally considered reasonable by both industry and the community. The scenario represented a low to medium growth situation, where capacity of the Dempster Lateral pipeline was considered to be the "cap" on potential levels of natural gas development. If larger reserves of natural gas were discovered, and pipeline capacity was increased, the level of energy sector activity in Eagle Plain could increase substantially. Scenario results presented in this paper may therefore be conservative.

Exploring other scenarios with different levels of natural gas reserves or additional pipeline capacity would have broadened the understanding of possible energy sector futures in North Yukon. However, modeling a single oil and gas scenario, and then performing sensitivity around selected parameters, resulted in the desired learnings of the scenario modeling exercise. A large number of scenarios with different assumptions and parameters would have made the communication and interpretation of results challenging.

Regardless of production levels, energy sector operating practices may play a large role in decreasing potential impacts to valued wildlife species and habitats (Table 5). Model results suggest that minimizing the amount of all-season access roads is the most important strategy for reducing impacts on barrenground caribou and moose. Development of an all-season access road network within Eagle Plain would be the most 
Table 4. Eagle Plain oil and gas scenario results.

\begin{tabular}{|c|c|}
\hline Indicator & Eagle Plain oil and gas scenario \\
\hline \multicolumn{2}{|l|}{ Socioeconomic indicators } \\
\hline Commodity production & Based on 30-year play: 2.0 trillion cubic feet natural gas, 2.74 million barrels oil \\
\hline \multirow[t]{2}{*}{ Revenue } & Based on $\$ 10 /$ million cubic feet natural gas: $\$ 500$ million- $\$ 1.2$ billion/yr \\
\hline & Based on $\$ 60 /$ barrel oil: $\$ 30$ million/yr \\
\hline \multirow[t]{2}{*}{ Employment (annual) } & Exploration: 120 annual full-time equivalent positions for 20 - to 30 -year period \\
\hline & Production: $300-350$ annual full-time equivalent positions for 30 -year period \\
\hline Wages (annual) & $\$ 36$ million at peak production \\
\hline Royalties $^{\dagger}$ & Based on $\$ 10 /$ million cubic feet natural gas and $10 \%$ royalty rate: $\$ 50-\$ 120$ million/yr \\
\hline Regional population & $\begin{array}{l}\text { Additional 300-350 full-time energy sector workers in region (housed in work camps) for 30-year } \\
\text { period }\end{array}$ \\
\hline \multicolumn{2}{|c|}{ Ecological and land use indicators } \\
\hline Maximum surface disturbance ${ }^{\ddagger}$ & $7500-20,000$ ha \\
\hline 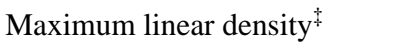 & $0.7-1.3 \mathrm{~km} / \mathrm{km}^{2}$ \\
\hline $\begin{array}{l}\text { Barren-ground caribou winter } \\
\mathrm{HEI}^{\S}\end{array}$ & $20-40 \%$ reduction \\
\hline Moose late-fall $\mathrm{HEI}^{\S}$ & $20-40 \%$ reduction \\
\hline
\end{tabular}

${ }^{\dagger}$ Royalty rates fluctuate in response to price and production. Beyond a certain royalty level, most resource royalties would flow back to the federal government and would not be retained by Yukon.

${ }^{\ddagger}$ Surface disturbance and linear density reported as a range of maximum values. Operating practices and reclamation assumptions have a significant influence on potential levels of disturbance and the life span of those disturbances.

${ }^{\S}$ Focal wildlife species Habitat Effectiveness Index (HEI) values are presented as a range of maximum and minimum values related to the maximum and minimum surface disturbance and linear density indicator levels. HEI value is reported as percent reduction compared with RNV results.

significant long-term management issue associated with energy sector activity.

As described in the sensitivity analysis, increasing snow depth and hardness may have a greater adverse effect on barrenground caribou winter habitat quality in Eagle Plain than the oil and gas scenario as examined. The potential combined effects of climate change-induced changes in snow conditions and increasing energy sector activity require a cautious management approach for the NYPR.

\section{Support for planning recommendations}

The NYRLUP accepts that land uses result in some level of impact, but that within limits, impacts are acceptable and sustainable. Scenario modeling results supported the recommendations and cumulative effects management guidelines of the NYRLUP (NYPC 2007a). Critical and cautionary cumulative effects indicator levels were recommended based on the simulated levels of surface disturbance and linear density associated with the Eagle Plain oil and gas scenario (Tables 1 and 5).

For example, scenario modeling results suggested that a moderate level of oil and gas exploration and production could occur in the Eagle Plain basin while maintaining total surface disturbance and linear density at less than one percent and 1 $\mathrm{km} / \mathrm{km}^{2}$ of the area, respectively, provided that a number of best management practices were followed (Table 5). Considering potential risks to valued resources, the NYPC recommended these disturbance levels to be acceptable in the Eagle Plain area in order to achieve desired economic benefits. However, to achieve regional conservation objectives, lower cumulative surface disturbance and linear density guidelines were recommended for other parts of the NYPR, as designated by the zoning system.

In this manner, the scenario modeling approach supported land use zoning and cumulative effects recommendations. The planning support provided by $\mathrm{ALCES}^{\circledR}$ and land use scenario modeling ultimately assisted with the formal approval and adoption of the NYRLUP (Yukon Government and Vuntut Gwitchin Government 2009) by creating buy-in from different stakeholder groups, and by demonstrating a balanced approach to conservation planning and economic development.

\section{Other benefits of scenario modeling}

While modeling results supported planning recommendations, the activities associated with the modeling process itself also had several benefits. These include increased communication and understanding of land uses and ecology, identification of key drivers of change, and improved understanding of socioeconomic and ecological trade-offs. Similar experiences were noted by Sandker et al. (2010). 
Table 5. Comparison of different oil and gas operating practices (best management practice) scenarios and their relative effect on average barren-ground caribou winter Habitat Effectiveness Index (HEI) and average moose late-fall HEI at year 50 of simulation period.

\begin{tabular}{llll}
\hline \hline Parameter & $\begin{array}{l}\text { BMP } \dagger \\
\text { scenario 1 }\end{array}$ & $\begin{array}{l}\text { BMP } \\
\text { scenario 2 }\end{array}$ & $\begin{array}{l}\text { BMP } \\
\text { scenario 3 }\end{array}$ \\
\hline Average seismic line width & $5 \mathrm{~m}$ & $3 \mathrm{~m}$ or less & $3 \mathrm{~m}$ or less \\
Seismic line lifespan & 30 years & 10 years & 10 years \\
Number of wells per pad & 1 & 1 & 4 \\
Maximum surface disturbance & 20,000 ha & $15,000 \mathrm{ha}$ & $7,500 \mathrm{ha}$ \\
& $(1.4 \%)$ & $(1.1 \%)$ & $0.5 \%)$ \\
Maximum linear density & $1.3 \mathrm{~km} / \mathrm{km}^{2}$ & $0.9 \mathrm{~km} / \mathrm{km}^{2}$ & $0.7 \mathrm{~km} / \mathrm{km}^{2}$ \\
Barren-ground caribou winter HEI & 0.40 & 0.48 & 0.59 \\
Moose late-fall HEI & 0.25 & 0.28 & 0.40 \\
\hline
\end{tabular}

†best management practices

\section{Communication and understanding}

Effective land use planning requires effective communication and understanding of planning issues. Through the use of workshops and focused working groups, the scenario modeling approach used to support the NYRLUP fostered collaboration and increased understanding between domain experts, planners, and decision-makers. Discussing information, stating assumptions, creating impact hypothesis diagrams, and developing scenario parameters allowed each group to have direct input into the modeling process, and ultimately built support for results and plan recommendations.

However, it is important to recognize that our scenario modeling exercise was focused primarily on domain experts and government participants with decision-making powers. Key learnings were communicated to the community of Old Crow through the NYRLUP and discussions surrounding it, but community members did not participate directly in the scenario modeling itself. How this potentially affected outcomes is uncertain.

Our decision to focus on domain experts was necessitated by limited time and resources. Direct, meaningful community member engagement in the scenario modeling process would have required significant human resources beyond what the NYPC could have provided, but should be considered in future exercises.

\section{Identification of key drivers of change}

The ALCES ${ }^{\circledR}$ model was well suited to identifying key drivers of change and illustrating the relative effect and potential magnitude of those changes. This resulted in a more objective "evidence-based" discussion of potential land use impacts. For example, some resource managers had previously failed to grasp the large effects that snow conditions and fire regimes can have on caribou habitat conditions. Similarly, the model helped enhance the understanding of key land use parameters by illustrating the linkage between the level of oil and gas activity, operating practices, and road density.

\section{Improved understanding of trade-offs}

Land use planning participants and decision-makers often have difficulty understanding the nature and magnitude of potential trade-offs that may exist between conservation and socioeconomic considerations. In North Yukon, previous land and resource discussions generally focused on absolute choices-conservation versus development, or more specifically, caribou herd health versus oil and gas development. The ALCES $^{\circledR}$ model helped demonstrate that within limits, and if well managed, oil and gas development could potentially occur in Eagle Plain and provide desired economic benefits without causing unacceptable impacts on caribou habitat. Conversely, in order to maintain desired caribou values, high levels of oil and gas development could not occur everywhere, and would have to be carefully managed with a focus on linear feature reduction and access management.

\section{Future uncertainty}

Projections of future land use and environmental conditions are uncertain. The Eagle Plain oil and gas scenario examined in this exercise is based on specific assumptions about the rate, location, and operating practices of the activity. Government policy, global commodity prices, trends in energy supply and transportation infrastructure, and technological innovation all affect the potential intensity and location of future land use activities. It is probable that the scenario assumptions used in this project may not be valid 20 or 30 years in the futureeconomic conditions and policy decisions may result in very different future land use outcomes. For example, it is possible that oil and gas development in the Eagle Plain region may never be realized. Similarly, climate change impacts may be 
of different magnitude than anticipated, resulting in variable stresses to wildlife and cultural systems.

While future conditions are uncertain, examining plausible futures based on current assumptions allows potential socioeconomic benefits and environmental impacts to be understood and evaluated today, with a focus on risk management. Evaluating potential risks and benefits of land use is central to developing and implementing sustainable development strategies that can be re-evaluated as circumstances change. Similar to the precautionary principle, uncertainty about future land use activities should not impede progressive and cautionary approaches to land management today.

\section{CONCLUSION}

Land use scenario modeling was an effective process for facilitating an informed discussion about the potential benefits and risks of oil and gas development in the Eagle Plain area of northern Yukon. Scenario modeling results directly supported planning recommendations of the NYRLUP. The ALCES $^{\circledR}$ landscape cumulative effects simulation model was effective in facilitating increased communication and understanding between participants, identifying key drivers of change, and highlighting the type and magnitude of potential trade-offs between conservation and socioeconomic considerations. Use of the model facilitated a more neutral, objective discussion of potential risks and benefits of land use than had previously been possible, ultimately leading to greater acceptance and adoption of the NYRLUP.

The NYRLUP attempts to balance potential risks to ecological and cultural resources with the requirement for, and potential impacts of, economic development. Understanding and managing potential cumulative land use impacts is central to achieving this goal. Scenario modeling approaches, as applied in this project, can assist in establishing guidelines for sustainable levels of development and associated impacts through regional planning processes.

Responses to this article can be read online at: http://www.ecologyandsociety.org/vol16/iss4/art18/ responses/

\section{Acknowledgments:}

This project was made possible through funding assistance from the following agencies: Environment Canada Northern Ecosystems Initiative; Yukon Land Use Planning Council; and Yukon Government, Oil and Gas Management Branch. The authors wish to say a special Mahsi Cho (thank you) to the North Yukon Planning Commission members, Shirlee Frost (Chair), Dave Brekke, Dennis Frost Sr., Jane Montgomery, and Marvin Frost Sr., the community of Old Crow, and the Yukon Land Use Planning Council Director, Ron Cruikshank, for their support and encouragement. Dr. Brad Stelfox, Terry
Antoniuk, John Ryder, Richard Vladars, and many Yukon Government, Vuntut Gwitchin Government, federal agency staff, and industry representatives provided valuable technical assistance and information.

\section{LITERATURE CITED}

ALCES Landscape and Land-Use Ltd. (ALCES). 2011. ALCES $^{\circledR}$ documentation. [online] URL: http://www.alces.ca/ home/ALCES Products/Integrator

Arctic Climate Impacts Assessment (ACIA). 2005. Impacts of a warming Arctic: Arctic climate impacts assessment. Cambridge University Press, Cambridge, England.

Berman, M., and G. P. Kofinas. 2004. Hunting for models: grounded and rational choice approaches to analysing climate effects on subsistence hunting in an Arctic community. http:/ /dx.doi.org/10.1016/S0921-8009(04)00038-2

Ecological Economics 49:31-46.

Berman, M., C. Nicolson, G. P. Kofinas, J. Tetlichi, and S. Martin. 2004. Adaptation and sustainability in a small Arctic community: results of an agent-based simulation model. Arctic $57: 401-414$.

Cameron, R. D., W. T. Smith, R. G. White, and B. Griffith. 2005. Central Arctic caribou and petroleum development: distributional, nutritional, and reproductive implications. Arctic 58:1-9.

Duinker, P. N., and L. A. Greig. 2006. The impotence of cumulative effects assessment in Canada: ailments and ideas for redeployment. Environmental Management 37:153-161. http://dx.doi.org/10.1007/s00267-004-0240-5

Duk-Rodkin, A. 1999. Glacial limits map of Yukon Territory. Geological Survey of Canada Open File 3288 and Yukon Geological Survey Open File 1999-2 (1:1,000,000 scale). htt p://dx.doi.org/10.4095/210739

Fekete and Associates Inc., and Vector Research (Fekete). 2006. North Yukon conceptual oil and gas development scenario and local benefits assessment. Unpublished report prepared for North Yukon Oil and Gas Working Group, Whitehorse, Yukon, Canada. March 2006.

Greig, L. A., K. Pawley, and P. N. Duinker. 2004. Alternative scenarios of future development: an aid to cumulative effects assessment. Prepared for Canadian Environmental Assessment Agency, Gatineau, Quebec by ESSA Technologies Ltd., Richmond Hill, Ontario, Canada. [online] URL: http://www.a cee-ceaa.gc.ca/default.asp?lang=En\&n=2DEF0B57-1

Government of Yukon, Council of Yukon Indians and Government of Canada. 1993a. Yukon Umbrella Final Agreement. Department of Indian Affairs and Northern Development, Ottawa, Ontario, Canada.

Government of Yukon, Council of Yukon Indians and Government of Canada. 1993b. Vuntut Gwitchin First Nation 
Final Agreement. Department of Indian Affairs and Northern Development, Ottawa, Ontario, Canada.

Hinzman, L. D., N. D. Bettez, W. R. Bolton, F. S. Chapin, M. B. Dyurgerov, C. L. Fastie, B. Griffith, R. D. Hollister, A. Hope, H. P. Huntington, A. M. Jensen, G. J. Jia, T. Jorgenson, D. L. Kane, D. R. Klein, G. Kofinas, A. H. Lynch, A. H. Lloyd, A. D. McGuire, F. E. Nelson, W. C. Oechel, T. E. Osterkamp, C. H. Racine, V. E. Romanovsky, R. S. Stone, D. A. Stow, M. Sturm, C. E. Tweedie, G. L. Vourlitis, M. D. Walker, D. A. Walker, P. J. Webber, J. M. Welker, K. S. Winker, and J. Yoshikawa. 2005. Evidence and implications of recent climate change in Northern Alaska and other Arctic regions. Climatic Change 72:251-298. http://dx.doi.org/10.1007/s10584-005-5352-2

Hopkins, D. M., J. V. Matthews Jr., C. E. Schweger, and S. B. Young, editors. 1982. Paleoecology of Beringia. Academic Press, New York.

isee systems. 2010. isee systems online documentation for Stella ${ }^{\Theta}$ and iThink ${ }^{\odot}$ software. [online] URL: http://www.isees ystems.com/

Kennett, S. A. 1999. Towards a new paradigm for cumulative effects management. CIRL Occasional Paper \#8, Canadian Institute of Resources Law, Calgary, Alberta, Canada.

Kruse, J. A., R. G. White, H. E. Epstein, B. Archie, M. Berman, S. R. Braund, F. S. Chapin III, J. Charlie Sr., C. J. Daniel, J. Eamer, N. Flanders, B. Griffith, S. Haley, L. Huskey, B. Joseph, D. R. Klein, G. P. Kofinas, S. M. Martin, S. M. Murphy, W. Nebesky, C. Nicolson, D. E. Russell, J. Tetlichi, A. Tussing, M. D. Walker, and O. R. Young. 2004. Modeling sustainability of Arctic communities: an interdisciplinary collaboration of researchers and local knowledge holders. Ecosystems 7:815-828. http://dx.doi.org/10.1007/s10021-004 $\underline{-0008-\mathrm{Z}}$

Mackenzie Gas Project. 2010. The project. Imperial Oil Resources Ventures Ltd., ConocoPhillips Canada (North) Ltd., Shell Canada Ltd., ExxonMobil Canada Properties, and Aboriginal Pipeline Group.

Macleod Institute. 2002. Carrying capacity and thresholds: theory and practice in environmental management. Prepared for Canadian Arctic Resources Committee, Calgary, Alberta, Canada. [online] URL: http://www.macleodinstitute.com/pub lications/capacity.php

Mahmoud, M., Y. Liu, H. Hartmann, S. Stewart, T. Wagener, D. Semmens, R. Stewart, H. Gupta, D. Dominguez, F. Dominguez, D. Hulse, R. Letcher, B. Rashleigh, C. Smith, R. Street, J. Ticehurst, M. Twery, H. van Delden, R. Waldick, D. White, and L. Winter. 2009. A formal framework for scenario development in support of environmental decision-making. Environmental Modeling and Software 24:798-808. http://dx. doi.org/10.1016/j.envsoft.2008.11.010
Nellemann, C., and R. D. Cameron. 1998. Cumulative impacts of an evolving oil-field complex on the distribution of calving caribou. Canadian Journal of Zoology 76:1425-1430. http:// dx.doi.org/10.1139/z98-078

North Yukon Planning Commission (NYPC). 2007a. Draft North Yukon regional land use plan. Nichih Gwanal'inLooking Forward. October 2007. Whitehorse, Yukon, Canada. [online] URL: http://www.planyukon.ca/index.php/d ocuments/cat_view/81-north-yukon-planning-commissiondocuments/133-regional-plans/101-draft-plan.html

North Yukon Planning Commission (NYPC). 2007b. North Yukon Planning Region resource assessment report. October, 2007. Whitehorse, Yukon, Canada. [online] URL: http://www .planyukon.ca/index.php/documents/cat_view/81-north-yukonplanning-commission-documents/99-resource-assessment-reportmaps-a-posters/134-resource-assessment-report.html

Osadetz, K. G., Z. Chen, and T. D. Bird. 2005. Petroleum resource assessment, Eagle Plain Basin and environs, Yukon Territory, Canada. Yukon Geological Survey Open File 2005-2, Geological Survey of Canada Open File 4922. http:// dx.doi.org/10.4095/222501

Russell, D.E., A. M. Martell, and W. A. C. Nixon. 1993. Range ecology of the Porcupine caribou herd in Canada. Rangifer Special Issue No. 8.

Salmo Consulting Inc., in association with AXYS Environmental Consulting Ltd., Forem Technologies and Wildlife \& Company Ltd. 2004. Deh Cho cumulative effects study. Phase I: management indicators and thresholds. Unpublished report prepared for Deh Cho Land Use Planning Committee. [online] URL: http://www.dehcholands.org/docs/ reports/Contractor\%20Reports/Cumulative\%20Effects\%20Report/ Cumulative\%20Effects\%20Phase1\%20Report Final.pdf

Sandker, M., B. M. Campbell, M. Ruiz-Perez, J. A. Sayer, R. Cowling, H. Kassa, and A. T. Knight. 2010. The role of participatory modeling in landscape approaches to reconcile conservation and development. Ecology and Society 15 (2):13.

Schneider, R. R., J. B. Stelfox, S. Boutin, and S. Wasel. 2003. Managing the cumulative impacts of land uses in the Western Canadian Sedimentary Basin: a modeling approach. Conservation Ecology 7(1):8.

Smith, C. A. S., J. C. Meikle, and C. F. Roots, editors. 2004. Ecoregions of the Yukon Territory: biophysical properties of Yukon landscapes. PARC Technical Bulletin No. 04-01, Agriculture and Agri-Food Canada, Summerland, British Columbia, Canada.

Trombulak, S., and C. Frissell. 2000. Review of ecological effects of roads on terrestrial and aquatic communities. 
Conservation Biology 14:18-30. http://dx.doi.org/10.1046/j.1 $\underline{\text { 523-1739.2000.99084.X }}$

Wahl, H. E., D. B. Fraser, R. C. Harvey, and J. B. Maxwell. 1987. Climate of Yukon. Atmospheric Environment Service, Environment Canada, Ottawa, Ontario, Canada.

Xiang, W., and K. C. Clarke. 2003. The use of scenarios in land-use planning. Environment and Planning 30:885-909. http://dx.doi.org/10.1068/b2945

Yukon Environmental and Socio-economic Assessment Act. 2003. [online] URL: http://www.yesab.ca/act regulations/do cuments/YESAAACTBillC-2.pdf

Yukon Government and Vuntut Gwitchin Government. 2009. North Yukon regional land use plan. Nichih Gwanal'inLooking Forward. June 2009. Whitehorse, Yukon, Canada. [online] URL: http://www.emr.gov.yk.ca/lands/nyrlup.html 